\title{
The Promotive Effect of Different Concentrations of Marine Algae on Spinach Plants (Spinacia oleracea L.)
}

\author{
Soad M. Mohy El-din* and Shimaa M. Hassan ** \\ *Department of Botany and Microbiology, Faculty of Science, \\ and ${ }^{* *}$ Department of Vegetable, Faculty of Agriculture, \\ Alexandria, Egypt.
}

\begin{abstract}
FIELD experiments were carried out during the winter seasons 2013/2014, 2014/2015 at the Experimental Station Farm of the Faculty of Agriculture, Alexandria University, at Abeis, Alex, governorate, A.R.E. to study the promotive effect of different concentrations of marine algae as biostimulantfertilization and mineral fertilization on growth and yield of Spinach, three of algae were applied in four rates $(5 \%, 10 \%, 20 \%$ and $40 \%)$ and sprayed alone or in combination with others and recommended NPK as a control were applied . Plants were harvested after 50 days from planting and the characters were measured such as (plant height $(\mathrm{cm})$, fresh and dry weights of leaves (\%), total yield, total leaf's chlorophyll content, mineral contents of leaves and the accumulation of nitrate). All the tested treatments increased plant yield and quality in varying degrees. Ulva lactuca + Bread yeast $5 \%$ was the best treatment to increase the yield of Spinach plants in addition was recorded the lowest amount of nitrate in Spinach leaves. We can evaluate the effect of seaweed extract on nitrogen metabolism in root and leaves of Spinach plants cultivated in medium culture deficiency or richened of mineral elements.
\end{abstract}

Keywords: Algae, Biostimulant, Nitrate content, Spinach.

Spinach (Spinacia oleracea L.) is one of the vegetables having inherently high nitrate concentration and petioles have several fold higher concentration than leaf blades. High nitrate concentration is found in leafy vegetables practically under intensive nitrogen fertilization. Nitrogen is usually the most abundant element in plants. Intensive application of fertilizer caused an excess of nitrogen for crops. There is strong evidence that some of the excess nitrogen taken up by the plant is not converted to protein but remains as non-protein nitrogen. This is not only inefficient use of nitrogen by the plant but leads to inefficient use by the animal and the risk of ill effects on human beings eating the plant. Mordogan (2000) pointed out that spinach yield increased with the increases in $\mathrm{N}$ level, furthermore, increased the soluble $\mathrm{N}$ compounds in the plant. Paradiso et al. (2001) stated that leaf nitrate content increased in the last two weeks before harvest and was highest with the maximum $\mathrm{N}$ rate. Karaman et al. (2000) stated that the nitrate content in the vegetables were increased with increasing regional $\mathrm{N}$ use especially $\mathrm{NO}_{3}-\mathrm{N}$, accumulation nitrate of vegetables increased much more than $\mathrm{NH}_{4}-\mathrm{N}$, Wang et al. (2003). 
Nitrate is a naturally occurring form of nitrogen and it is an integral part of the nitrogen cycle in the environment. Nitrate is formed from fertilizers, decaying plants, manure and other organic residues. It is found in the air, soil, water and food (particularly in vegetables) and it is produced naturally within the human body. Walker (1990) and Speijers (2003). It is also used as a food additive, mainly as a preservative and antimicrobial agent. Speijers (1996 and 2003) It is used in foods such as cheese and cheese products, raw and processed meats, edible casings, processed fish, fish products, spirits and liqueurs. Due to the increased use of synthetic nitrogen fertilizers and livestock manure in intensive agriculture vegetables and drinking water may contain higher concentrations of nitrate than in the past.

Soil fertility is diminishing gradually due to soil erosions, loss of nutrient, accumulation of salts and other toxic elements, water logging and un-balanced nutrient compensation. Organic wastes and bio-fertilizers are the alternate sources to meet the nutrient requirement of crops and to bridge the future gaps. Farming regions that emphasizing heavy chemical application led to adverse environmental, agricultural and health consequences. Many efforts are being exercised to combat the adverse consequences of chemical farming (Faheed and Abd-El-Fattah, 2008).

Algae and active bread yeast extract have a positive effect on fruit setting, yield and fruit quality (Hegab et al., 2005 and Abd El-Motty et al., 2010). Algae extract as a new bio-fertilizer containing $\mathrm{N}, \mathrm{P}, \mathrm{K}, \mathrm{Ca}, \mathrm{Mg}$, and $\mathrm{S}$ as well as $\mathrm{Zn}$, $\mathrm{Fe}, \mathrm{Mn}, \mathrm{Cu}$, Mo and $\mathrm{Co}$, some growth regulators, polyamines, natural enzymes, carbohydrates, proteins and vitamins applied to improve nutritional status, vegetative growth, yield and fruit quality in different orchard as well as vineyards (Abd El-Migeed et al., 2004, Abd El-Moniem \& Abd-Allah, 2008, Spinelli et al., 2009 and Abbas, 2013).

Nowadays, braed yeast (Saccaromycescervisiae) as a natural bio-stimulant appeared to induce an important influence on growth and yield of many crops, since it has various basic function, i.e. $\mathrm{CO}_{2}$ production as well as formation of alcohol, acids and esters (Martinez-Anoya et al., 1990). Active dry yeast is a natural safety bio-fertilizer, it is considered as a natural source of cytokinins that stimulates cell division and enlargement as well as the synthesis of protein and nucleic acid (Mady, 2009). Spraying Valencia orange trees with active bread yeast either once on March or August or twice at both dates was favorable in improving growth, fruit set, number of fruits and yield as well as fruit weight and volume (Hegab et al., 2005). Ahmed and Ragab (2002) supported the beneficial effect of yeast on nutritional status of Picual olive trees.

In addition, bio-organic is very safe for human, animal and environment to get lower pollution and reduce soil salinity via decrease mineral usage fertilization as well as saving fertilization cost. The present study aimed to assess the effect of these biostimulants on yield and growth of Spinaciaoleracea.

Egypt. J. Hort. Vol. 43, No.1 (2016) 


\section{Materials and Methods}

The seaweeds used in this study were Ulva lactuca (class: Chlorophyceae) and Jainarubens (class: Rhodophyceae). They were collected from the coastal area of Abu-Kir, Alexandria-north of Egypt. The samples were washed thoroughly with seawater to remove all the unwanted impurities, adhering sand particles and epiphytes. The samples were placed separately in polythene bags, kept inside an ice box and transported to the laboratory. Samples were washed thoroughly using tap water to remove surface salt and spread on blotting paper to remove excess water. Samples were air-dried $\left(25^{\circ} \mathrm{C}\right)$ during $2-4$ days followed by dry at $60^{\circ} \mathrm{C}$ for 12 hours.

Dried seaweeds were hand crushed and powdered with coffee-grinder. Algae were heated with sterile distilled water in a ratio $1: 100(\mathrm{w} / \mathrm{v})$ at $60^{\circ} \mathrm{C}$ for 45 minutes, and then the extracts were filtrated through a filter paper and stored at $4^{\circ} \mathrm{C}$ for further experimental studies. The filtrate were $10^{-2} \mathrm{~g}$ of dried seaweeds per milliliter $\left(\mathrm{g}\right.$ DSW ml $\left.\mathrm{m}^{-1}\right)$ extracts. The filtrate were considered as $100 \%$ seaweed extracts and different concentrations of seaweed liquid extract (SLE) were prepared by diluting of these extracts with distilled water. Such concentrations $5 \%, 10 \%, 20 \%$ and $40 \%$ were used in our experiment (Bhasle et al., 1975 and Anisimov et al., 2013). The major components of the used algae are shown in Table 1.

TABLE 1. Physic-chemical composition and mineral contents of Ulva lactucaand Jainarubensextracts .

\begin{tabular}{|l|c|c|}
\hline Parameters & Ulva lactuca & Jainarubens \\
\hline Color & Green & Red \\
\hline $\mathrm{pH}$ & 6.63 & 6.68 \\
\hline Ash\% & 37.15 & 42.40 \\
\hline Moisture content\% & 11.76 & 9.95 \\
\hline Protein\% & 15.65 & 6.396 \\
\hline Carbohydrate\% & 29.60 & 6.146 \\
\hline Lipid\% & 0.82 & 1.014 \\
\hline Nitrogen $(\mathrm{mg} / \mathrm{kg})$ & 474 & 523 \\
\hline Phosphorus $(\mathrm{mg} / \mathrm{kg})$ & 93 & 288.53 \\
\hline Potassium $(\mathrm{mg} / \mathrm{kg})$ & 1570 & 1454 \\
\hline Sodium $(\mathrm{mg} / \mathrm{kg})$ & 2065 & 4400 \\
\hline Manganese $(\mathrm{mg} / \mathrm{kg})$ & 37.7 & 149.44 \\
\hline Calcium $(\mathrm{mg} / \mathrm{kg})$ & 1892 & 3776.1 \\
\hline Magnesium $(\mathrm{mg} / \mathrm{kg})$ & 3334 & 3952.2 \\
\hline Iron $(\mathrm{mg} / \mathrm{kg})$ & 228.6 & 45 \\
\hline Zinc $(\mathrm{mg} / \mathrm{kg})$ & 42.16 & 123 \\
\hline Copper $(\mathrm{mg} / \mathrm{kg})$ & 5.7 & 4.1 \\
\hline Cobalt $(\mathrm{mg} / \mathrm{kg})$ & 0.6 & 1.0 \\
\hline Cadmium $(\mathrm{mg} / \mathrm{kg})$ & 0.27 & 0.157 \\
\hline Chromium $(\mathrm{mg} / \mathrm{kg})$ & 0.87 & 0.051 \\
\hline Nickel $(\mathrm{mg} / \mathrm{kg})$ & 5.51 & 6.0 \\
\hline Lead $(\mathrm{mg} / \mathrm{kg})$ & 1.0 & 6.1 \\
\hline & & \\
\hline
\end{tabular}

Egypt. J. Hort. Vol. 43, No.1 (2016) 
Bread yeast was applied in four rates $(5 \%, 10 \%, 20 \%$ and $40 \%)$ and sprayed alone or in combination with seaweed treatments. The chemical composition of bread yeast are shown in Table 2 .

TABLE 2. Chemical composition of Saccharomyces cerevisiae (bread yeast) (after, Nagodawithana, 1991).

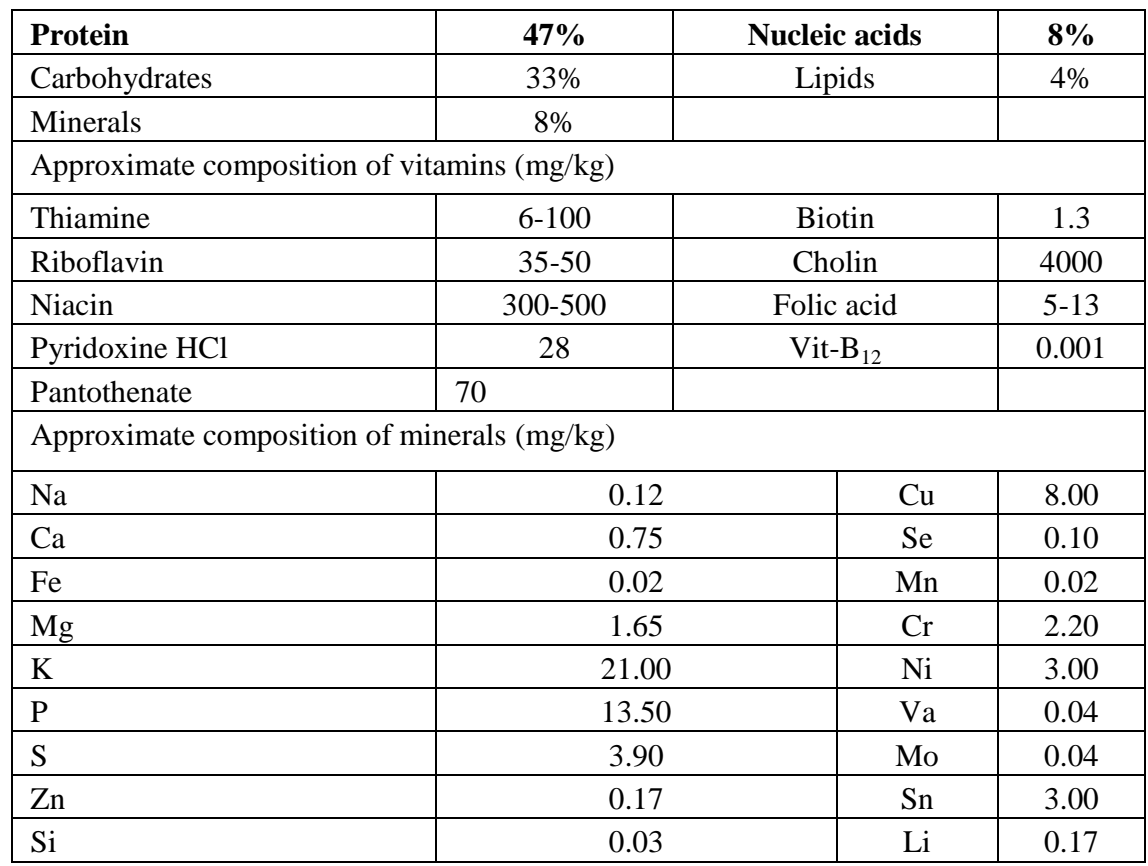

In the field this study was conducted during the two winter seasons of 2013/2014, 2014/2015 at the Experimental Station Farm of the Faculty of Agriculture, Alexandria University, at Abeis, Alex, governorate, A.R.E.

Some physical and chemical characteristics of the experimental soil atFaculty of Agriculture, Alexandria University are shown in Table 3.

Three of algae were applied in four rates $(5 \%, 10 \%, 20 \%$ and $40 \%)$ as biostimulant and NPK fertilization (control) were used in the present study. Commercial Spinach cultivar (Baldy) was used in this experiment .Seeds of spinach were sown on $25^{\text {th }}$ of November, in both seasons. Three replicates per treatment (each replicate contained 25 treatments). NPK fertilization was carried out according to the recommendations for commercial production of spinach plant as outlined by Ministry of Agriculture and Land Reclamation-Arab Republic of Egypt. The NPK treatment consisted in ammonium nitrate $(33 \% \mathrm{~N})$ at the rate of 5 $\mathrm{kg} 100 \mathrm{~m}^{-2}$, calcium super phosphate at the rate of $6,25 \mathrm{~kg} 100 \mathrm{~m}^{-2}$, potassium sulphate $\left(48 \% \mathrm{~K}_{2} \mathrm{O}\right)$ at the rate of $1.25 \mathrm{~kg} 100 \mathrm{~m}^{-2}$.

Egypt. J. Hort. Vol. 43, No.1 (2016) 
TABLE 3. Soil's physical and chemical properties of the experimental sites in the tow winter seasons of 2013/2014 and 2014/2015 before cultivation.

\begin{tabular}{|c|c|c|}
\hline Properties & $\begin{array}{c}\text { Winter } \\
\text { 2013/2014 }\end{array}$ & $\begin{array}{c}\text { Winter } \\
\text { 2014/2015 }\end{array}$ \\
\hline \multicolumn{3}{|l|}{ Physical properties } \\
\hline Sand \% & 32.8 & 31.9 \\
\hline Silt \% & 25.2 & 25.8 \\
\hline Clay \% & 42.0 & 42.3 \\
\hline Soil texture & Clay loam & Clay loam \\
\hline \multicolumn{3}{|l|}{ Chemical properties } \\
\hline $\mathrm{pH}$ & 8.01 & 7.95 \\
\hline E.C. $\left(\mathrm{dS} . \mathrm{m}^{-1}\right)$ & 3.01 & 3.02 \\
\hline \multicolumn{3}{|l|}{ Soluble cations (meq/ l) } \\
\hline $\mathrm{Ca}^{++}$ & 2.41 & 2.30 \\
\hline $\mathrm{Mg}^{++}$ & 2.00 & 1.90 \\
\hline $\mathrm{Na}^{+}$ & 2.73 & 2.65 \\
\hline $\mathrm{K}^{+}$ & 0.46 & 0.36 \\
\hline \multicolumn{3}{|l|}{ Soluble anions (meq/ l) } \\
\hline $\mathrm{HCO}_{3}^{-}$ & 2.20 & 2.20 \\
\hline $\mathrm{Cl}^{-}$ & 2.00 & 1.90 \\
\hline $\mathrm{SO}_{4}^{--}$ & 3.40 & 3.11 \\
\hline Total N \% & 0.196 & 0.15 \\
\hline Available P ppm) & 0.337 & 0.286 \\
\hline
\end{tabular}

First application of biostimulant was done after two weeks from planting the second and the third applications were added every 15 days from the first dose.

Plants were harvested after 50 days from planting, ten plants were randomly chosen from the different treatments and their growth was measured based on plant height $(\mathrm{cm})$, fresh and dry weight of leaves, total yield, total leaf's chlorophyll content (mg 100g f.w.) according to the method described by Yadava (1986), mineral contents of leaves according to A.O.A.C. (1990) and the content of nitrate were determined at High Institute of public Health, Environmental Health Research, Analysis and Studies unit, Alexandria University.

Treatment means were separated and compared using the L.S.D test at 0.05 level of significance according to Snedecor and Cochran (1980). The statistical analysis was performed using CoStat software package for Windows.

Vegetative growth

\section{Results and Discussions}

With regard to the data presented in Table 4 Jainarubens + Ulva lactuca $40 \%$ had significantly higher value of plant height in two seasons. On the other hand, Jainarubens 5\% resulted in shorter plant height. From the results observed in Table 4 it is clear the high number of leaves per plant in both seasons was significantly by Jainarubens $20 \%$, the minimum number of leaves was 5.66 and 6.33 leaf/ plant produced by Ulva lactuca 5\% treatment during the first and second seasons, respectively. 
From the above results, it could be concluded that Jainarubensand Ulva lactucaas a bioorganic fertilizers for growing spinach plants. Seaweed products contain growth regulators (auxins, cytokinins and gibberellins), amino acids and mineral nutrients, that accordingly affect plant growth and division positively effect on increasing the plants height. This may be due to the improving effect of such treatments on nutritional status of the plants, which reflected on increasing plants height. The previous results are agreed with those obtained by Abbas (2013) and Al-Shakankery et al. (2014) who reported that the growth and yield of maize plants increased when used marine algae as biofertilizers.

TABLE 4. Plant height (cm) and number of leaves/plant of Spinach plants affected by different concentrations of marine algae and bread yeast as biostimulant, during the two winter seasons of 2013/2014 and 2014/2015.

\begin{tabular}{|c|c|c|c|c|}
\hline \multirow[b]{2}{*}{ Treatments } & \multicolumn{2}{|c|}{ Plant height $(\mathrm{cm})$} & \multicolumn{2}{|c|}{ N. of leaves /plant } \\
\hline & $\begin{array}{c}\text { Winter } \\
2013 / 2014\end{array}$ & $\begin{array}{c}\text { Winter } \\
\text { 2014/2015 }\end{array}$ & $\begin{array}{c}\text { Winter } \\
2013 / 2014\end{array}$ & $\begin{array}{c}\text { Winter } \\
2014 / 2015\end{array}$ \\
\hline Bread yeast $\quad 5 \%$ & 38.66 F-J & 39.33 F-J & $6.00 \mathrm{BC}$ & $6.66 \mathrm{BC}$ \\
\hline Bread yeast $\quad 10 \%$ & 39.66 E-I & 40.33 E-I & $6.00 \mathrm{BC}$ & $6.66 \mathrm{BC}$ \\
\hline Bread yeast $20 \%$ & 36.66 G-J & 37.33 G-J & $7.00 \mathrm{~A}-\mathrm{C}$ & $7.66 \mathrm{~A}-\mathrm{C}$ \\
\hline Bread yeast $\quad 40 \%$ & 39.33 E-J & $40.00 \mathrm{E}-\mathrm{I}$ & $6.33 \mathrm{~A}-\mathrm{C}$ & $7.00 \mathrm{~A}-\mathrm{C}$ \\
\hline Jainarubens $5 \%$ & $33.00 \quad \mathrm{~J}$ & $33.66 \mathrm{~J}$ & $6.66 \mathrm{~A}-\mathrm{C}$ & $7.33 \mathrm{~A}-\mathrm{C}$ \\
\hline Jainarubens $10 \%$ & 41.00 D-H & $41.66 \mathrm{D}-\mathrm{H}$ & $7.66 \mathrm{AB}$ & $7.66 \mathrm{~A}-\mathrm{C}$ \\
\hline Jainarubens $20 \%$ & 42.66 C-G & $43.33 \mathrm{C}-\mathrm{G}$ & $8.00 \mathrm{~A}$ & $8.66 \mathrm{~A}$ \\
\hline Jainarubens $40 \%$ & 45.33 B-E & 46.00 B-E & $6.00 \mathrm{BC}$ & $6.66 \mathrm{BC}$ \\
\hline Ulva lactuca $5 \%$ & $34.33 \mathrm{IJ}$ & $35.00 \mathrm{IJ}$ & $5.66 \mathrm{C}$ & $6.33 \mathrm{C}$ \\
\hline Ulva lactuca $10 \%$ & $33.33 \quad \mathrm{IJ}$ & $34.00 \mathrm{IJ}$ & $6.00 \mathrm{BC}$ & $6.66 \mathrm{BC}$ \\
\hline Ulva lactuca $20 \%$ & $38.00 \quad$ F-J & $38.66 \mathrm{~F}-\mathrm{J}$ & $7.33 \mathrm{~A}-\mathrm{C}$ & $8.00 \mathrm{~A}-\mathrm{C}$ \\
\hline Ulva lactuca $40 \%$ & $41.33 \mathrm{D}-\mathrm{H}$ & $42.00 \mathrm{D}-\mathrm{H}$ & $6.33 \mathrm{~A}-\mathrm{C}$ & $7.00 \mathrm{~A}-\mathrm{C}$ \\
\hline Jainarubens + Bread yeast $5 \%$ & $39.66 \mathrm{E}-\mathrm{I}$ & 40.33 E-I & $7.66 \mathrm{AB}$ & $8.33 \mathrm{AB}$ \\
\hline Jainarubens+ Bread yeast $10 \%$ & 39.66 E-I & 40.33 E-I & $7.66 \mathrm{AB}$ & $7.66 \mathrm{~A}-\mathrm{C}$ \\
\hline Jainarubens+ Bread yeast $20 \%$ & $41.33 \mathrm{D}-\mathrm{H}$ & $42.00 \mathrm{D}-\mathrm{H}$ & $6.33 \mathrm{~A}-\mathrm{C}$ & $7.00 \mathrm{~A}-\mathrm{C}$ \\
\hline Jainarubens+ Bread yeast $40 \%$ & $36.00 \quad$ H-J & $36.66 \mathrm{H}-\mathrm{J}$ & $7.00 \mathrm{~A}-\mathrm{C}$ & $7.66 \mathrm{~A}-\mathrm{C}$ \\
\hline Ulva lactuca + Bread yeast $5 \%$ & $51.33 \quad \mathrm{AB}$ & $52.00 \quad \mathrm{AB}$ & $7.00 \mathrm{~A}-\mathrm{C}$ & $7.66 \mathrm{~A}-\mathrm{C}$ \\
\hline Ulva lactuca + Bread yeast $10 \%$ & $41.00 \quad \mathrm{D}-\mathrm{H}$ & 41.66 D-H & $6.00 \mathrm{BC}$ & $6.66 \mathrm{BC}$ \\
\hline Ulva lactuca + Bread yeast $20 \%$ & $49.00 \quad \mathrm{~A}-\mathrm{C}$ & $49.66 \mathrm{~A}-\mathrm{C}$ & $6.00 \mathrm{BC}$ & $6.66 \mathrm{BC}$ \\
\hline Ulva lactuca + Bread yeast $40 \%$ & $41.00 \quad \mathrm{D}-\mathrm{H}$ & 41.66 D-H & $6.66 \mathrm{~A}-\mathrm{C}$ & $7.33 \mathrm{~A}-\mathrm{C}$ \\
\hline Jainarubens+ Ulva lactuca $5 \%$ & $43.33 \quad \mathrm{C}-\mathrm{F}$ & $44.00 \mathrm{C}-\mathrm{F}$ & $7.00 \mathrm{~A}-\mathrm{C}$ & $7.66 \mathrm{~A}-\mathrm{C}$ \\
\hline Jainarubens+ Ulva lactuca $40 \%$ & $43.00 \quad \mathrm{C}-\mathrm{G}$ & $43.66 \mathrm{C}-\mathrm{G}$ & $7.33 \mathrm{~A}-\mathrm{C}$ & $8.00 \mathrm{~A}-\mathrm{C}$ \\
\hline Jainarubens+ Ulva lactuca $20 \%$ & 46.33 A-D & 47.00 A-D & $6.00 \mathrm{BC}$ & $6.66 \mathrm{BC}$ \\
\hline Jainarubens+ Ulva lactuca $40 \%$ & $52.33 \mathrm{~A}$ & $53.00 \mathrm{~A}$ & $7.33 \mathrm{~A}-\mathrm{C}$ & $8.66 \mathrm{~A}$ \\
\hline RECOMMENTED N P K (CONTROL) & 36.66 G-J & 37.33 G-J & $6.33 \mathrm{~A}-\mathrm{C}$ & $7.66 \mathrm{~A}-\mathrm{C}$ \\
\hline
\end{tabular}

*Values followed by the same alphabetical letter(s) in common, within a particular group of means in each character, do not significantly differ, using Revised L.S.D test at 0.05 level of probability.

Egypt. J. Hort. Vol. 43, No.1 (2016) 


\section{Total Yield}

The results clarified the differences due to the studied factor on the total yield shown in Table 5. Results indicated that the total yield was significantly affected by different concentration of marine algae and NPK fertilization in both seasons, whereas the highest total yield was obtained using (Jainarubens + Ulva lactuca 40\%) 2784 and $2829 \mathrm{~g} / \mathrm{m}^{2}$ in both seasons, respectively. However, the lowest total yield was obtained when Jainarubens 10\%) treatment was applied, in both seasons. From the previous results, it is clear that yield was increased and reached the maximum by using Jainarubens + Ulva lactuca $40 \%$. The increment in yield may explained due to the positive effect of alga Jainarubens $40 \%$ in combination with Ulva lactuca $40 \%$ as bio-organic. The obtained results may confirm the previous work done by Abd El-Motty et al. (2010) who reported that yield of mango was increased by algae extracts.

TABLE 5. Total yield $\left(\mathrm{g} / \mathrm{m}^{2}\right)$ of spinach as affected by different concentrations of marine algae and bread yeast as biostimulant, during the two winter seasons of $2013 / 2014$ and $2014 / 2015$.

\begin{tabular}{|c|c|c|}
\hline \multirow[b]{2}{*}{ Treatments } & \multicolumn{2}{|c|}{ Total yield $\left(\mathrm{g} / \mathrm{m}^{2}\right)$} \\
\hline & $\begin{array}{c}\text { Winter } \\
\text { 2013/2014 }\end{array}$ & $\begin{array}{c}\text { Winter } \\
\text { 2014/2015 }\end{array}$ \\
\hline Bread yeast $5 \%$ & 2333 A-D & 2392 A-D \\
\hline Bread yeast $10 \%$ & 1888 D-F & $1948 \mathrm{D}-\mathrm{F}$ \\
\hline Bread yeast $20 \%$ & 2059 B-F & 2133 B-F \\
\hline Bread yeast $40 \%$ & 1984 C-F & $2029 \mathrm{C}-\mathrm{F}$ \\
\hline Jainarubens $5 \%$ & 1918 D-F & $1977 \mathrm{D}-\mathrm{F}$ \\
\hline Jainarubens $10 \%$ & $1570 \mathrm{EF}$ & $1626 \mathrm{~F}$ \\
\hline Jainarubens $20 \%$ & 1925 D-F & 1984 D-F \\
\hline Jainarubens $40 \%$ & 2177 A-F & 2236 A-F \\
\hline Ulva lactuca $5 \%$ & 2355 A-D & 2414 A-D \\
\hline Ulva lactuca $10 \%$ & 2266 A-D & 2325 A-D \\
\hline Ulva lactuca $20 \%$ & 1795 D-F & $1854 \mathrm{D}-\mathrm{F}$ \\
\hline Ulva lactuca $40 \%$ & $1881 \mathrm{D}-\mathrm{F}$ & 1953 D-F \\
\hline Jainarubens+ Bread yeast $5 \%$ & 2007 B-F & 2066 B-F \\
\hline Jainarubens+ Bread yeast $10 \%$ & 2392 A-D & 2451 A-D \\
\hline Jainarubens+ Bread yeast $20 \%$ & 1903 D-F & 1977 D-F \\
\hline Jainarubens+ Bread yeast $40 \%$ & $1570 \mathrm{EF}$ & $1692 \mathrm{EF}$ \\
\hline Ulva lactuca + Bread yeast $5 \%$ & $2148 \quad$ A-F & 2208 A-F \\
\hline Ulva lactuca + Bread yeast $10 \%$ & 2296 A-D & 2355 A-D \\
\hline Ulva lactuca + Bread yeast $20 \%$ & $2592 \mathrm{~A}-\mathrm{C}$ & 2644 A-C \\
\hline Ulva lactuca + Bread yeast $40 \%$ & $2622 \mathrm{AB}$ & $2681 \mathrm{AB}$ \\
\hline Jainarubens+ Ulva lactuca $5 \%$ & 2362 A-D & 2422 A-D \\
\hline Jainarubens+ Ulva lactuca $10 \%$ & 2296 A-D & 2355 A-D \\
\hline Jainarubens+ Ulva lactuca $20 \%$ & 2207 A-D & 2264 A-E \\
\hline Jainarubens+ Ulva lactuca $40 \%$ & $2784 \mathrm{~A}$ & 2829 A \\
\hline RECOMMENTED N P K (CONTROL) & 2044 B-F & 2103 B-F \\
\hline
\end{tabular}

*Values followed by the same alphabetical letter(s) in common, within a particular group of means in each column, do not significantly differ, using Revised L.S.D test at 0.05 level of probability.

Egypt. J. Hort. Vol. 43, No.1 (2016) 
Leaves dry weight

Data in Table 6 showed that there was significant effect of all different concentration of marine algae on leaves dry weight of spinach plants in both seasons compared with NPK fertilization. The best result was obtained with using (Jainarubens 10\%), in both seasons. Similar results were achieved by Shaaban et al. (2010), found to have beneficial effects, such as increased crop yield, increased uptake of nutrient and resistance to stress conditions, when such algae applied to soil. Optimization of the nutrient fixing and nutrient toxicity, enabling every element to play its role a harmony with other nutrients, which leads, in turn, to the best dry matter accumulation.

\section{Chemical composition}

Total chlorophyll content

Data obtained in Table 6 showed that the highest value was obtained with Jainarubens + Ulva lactuca $20 \%$ in two seasons 48.33 . On the other hand the lowest of the chlorophyll content with N P K (CONTROL). The important role of biostimuants on enhancing the leaf chlorophyll might be attributed to their action on increasing the availability of water and minerals the high chlorophyll content might have resulted from enhanced plant growth (Mady, 2009). Sargassumextract was effective in enhancing chlorophyll synthesis in Zea mays and Phaseolus mungo (Homme et al., 1992). Applying yeast to field bean plant increased content of chlorophyll a, b and total chlorophyll (Abbas, 2013).

\section{Mineral content}

Results of leaf mineral content as influenced by various applied treatments were presented in Tables 7 and 8 showed that all different concentration of marine algae on leaf's nitrogen content were significant compared with control treatment (NPK).Treatments with the same letter in common are not statistically differentvalue was obtained but the highest number was (Jainarubens 40\%) 2.23 and 2.27, respectively in two seasons followed by (Ulva lactuca + Bread yeast 5\%) 2.25 and 2.25 respectively in two seasons. However, the lowest leaf's nitrogen was obtained by(NPK). Data obtained in Table 7 showed that there was significant effects of marine algae treatments on leaf's nitrate accumulation \% of Spanish plants. The highest accumulation of nitrate was (Ulva lactuca 40\%) in two seasons. However, the lowest leaf's nitrate accumulation \% was obtained by (Jainarubens + Bread yeast $5 \%$ and Ulva lactuca + Bread yeast 5\%), in both seasons.

From the above mentioned results it could be noticed that nitrogen content in the leaves was significantly affected by treatments in both studied seasons. The concentration of bio-organic (Ulva lactuca + Bread yeast 5\%) improved nitrogen content in the leaves. These results are in agreement with those reported by Hegab et al. (2005) and El-Motty et al. (2010). 
THE PROMOTIVE EFFECT OF DIFFERENT CONCENTRATIONS ...

TABLE 6. Leaf's chlorophyll content (mg/100 $\mathrm{g}$ f.w) and leaf's dry matter content (\%) of spinach plants as affected by different concentrations of marine algae and bread yeast as biostimulant during the two winter seasons of 2013/2014 and 2014/2015.

\begin{tabular}{|c|c|c|c|c|}
\hline \multirow[t]{2}{*}{ Treatments } & \multicolumn{2}{|c|}{$\begin{array}{l}\text { Leaf's chlorophyll } \\
\text { content } \\
\text { (mg/100 g f.w) }\end{array}$} & \multicolumn{2}{|c|}{$\begin{array}{l}\text { Leaf's dry matter } \\
\text { content }(\%)\end{array}$} \\
\hline & $\begin{array}{c}\text { Winter } \\
\text { 2013/2014 }\end{array}$ & $\begin{array}{c}\text { Winter } \\
\text { 2014/2015 }\end{array}$ & $\begin{array}{c}\text { Winter } \\
\text { 2013/2014 }\end{array}$ & $\begin{array}{c}\text { Winter } \\
\text { 2014/2015 }\end{array}$ \\
\hline Bread yeast $5 \%$ & $39.00 \mathrm{AB}$ & $40.00 \mathrm{AB}$ & $22.33 \mathrm{~J}$ & $22.66 \mathrm{~K}$ \\
\hline Bread yeast $10 \%$ & $38.66 \mathrm{AB}$ & $39.66 \mathrm{AB}$ & $21.71 \mathrm{~L}$ & $21.65 \mathrm{~N}$ \\
\hline Bread yeast $20 \%$ & $39.00 \mathrm{AB}$ & $40.00 \mathrm{AB}$ & $23.44 \mathrm{G}$ & $23.42 \mathrm{G}$ \\
\hline Bread yeast $40 \%$ & $39.33 \mathrm{AB}$ & $39.50 \mathrm{AB}$ & $24.00 \mathrm{E}$ & $25.00 \mathrm{~A}$ \\
\hline Jainarubens $5 \%$ & $41.66 \mathrm{AB}$ & $42.66 \mathrm{AB}$ & $24.00 \mathrm{E}$ & $24.22 \quad \mathrm{D}$ \\
\hline Jainarubens $10 \%$ & $40.33 \mathrm{AB}$ & $41.33 \mathrm{AB}$ & $26.00 \mathrm{~A}$ & $25.00 \mathrm{~A}$ \\
\hline Jainarubens $20 \%$ & $41.33 \mathrm{AB}$ & $42.33 \mathrm{AB}$ & $24.66 \mathrm{C}$ & $23.66 \mathrm{~F}$ \\
\hline Jainarubens $40 \%$ & $39.00 \mathrm{AB}$ & $40.00 \mathrm{AB}$ & $22.00 \mathrm{~K}$ & $22.22 \mathrm{~L}$ \\
\hline Ulva lactuca $5 \%$ & $39.00 \mathrm{AB}$ & $40.00 \mathrm{AB}$ & $24.33 \mathrm{D}$ & $23.66 \mathrm{~F}$ \\
\hline Ulva lactuca $10 \%$ & $39.66 \mathrm{AB}$ & $40.66 \mathrm{AB}$ & $25.00 \mathrm{~B}$ & 24.66 B \\
\hline Ulva lactuca $20 \%$ & $41.00 \mathrm{AB}$ & $42.00 \mathrm{AB}$ & $24.33 \mathrm{D}$ & $24.45 \mathrm{C}$ \\
\hline Ulva lactuca $40 \%$ & $40.33 \mathrm{AB}$ & $41.33 \mathrm{AB}$ & $23.33 \mathrm{H}$ & $23.21 \quad \mathrm{I}$ \\
\hline Jainarubens+ Bread yeast $5 \%$ & $39.33 \mathrm{AB}$ & $40.33 \mathrm{AB}$ & $23.00 \mathrm{I}$ & $23.33 \mathrm{H}$ \\
\hline Jainarubens+ Bread yeast $10 \%$ & $38.00 \mathrm{AB}$ & $39.00 \mathrm{AB}$ & $23.66 \mathrm{~F}$ & $22.00 \quad \mathrm{M}$ \\
\hline Jainarubens+ Bread yeast $20 \%$ & $35.66 \mathrm{AB}$ & $36.66 \mathrm{AB}$ & $23.66 \mathrm{~F}$ & $23.33 \mathrm{H}$ \\
\hline Jainarubens+ Bread yeast $40 \%$ & $46.33 \mathrm{AB}$ & $47.00 \mathrm{AB}$ & $21.00 \mathrm{~N}$ & $21.33 \mathrm{O}$ \\
\hline Ulva lactuca + Bread yeast $5 \%$ & $43.33 \mathrm{AB}$ & $44.33 \mathrm{AB}$ & $23.33 \mathrm{H}$ & $23.66 \mathrm{~F}$ \\
\hline Ulva lactuca + Bread yeast $10 \%$ & $44.33 \mathrm{AB}$ & $45.00 \mathrm{AB}$ & $23.00 \mathrm{I}$ & $23.00 \mathrm{~J}$ \\
\hline Ulva lactuca + Bread yeast $20 \%$ & $42.00 \mathrm{AB}$ & $43.00 \mathrm{AB}$ & $24.33 \mathrm{D}$ & $23.66 \mathrm{~F}$ \\
\hline Ulva lactuca + Bread yeast $40 \%$ & $41.66 \mathrm{AB}$ & $42.66 \mathrm{AB}$ & $23.66 \mathrm{~F}$ & 23.66 \\
\hline Jainarubens+ Ulva lactuca $5 \%$ & $41.00 \mathrm{AB}$ & $42.00 \mathrm{AB}$ & $24.33 \quad \mathrm{D}$ & 23.00 \\
\hline Jainarubens+ Ulva lactuca $10 \%$ & $41.66 \mathrm{AB}$ & $42.66 \mathrm{AB}$ & $23.33 \mathrm{H}$ & 23.65 \\
\hline Jainarubens+ Ulva lactuca $20 \%$ & $48.33 \mathrm{~A}$ & $48.33 \mathrm{~A}$ & $23.66 \quad \mathrm{~F}$ & 23.66 \\
\hline Jainarubens+ Ulva lactuca $40 \%$ & $46.33 \mathrm{AB}$ & $47.00 \mathrm{AB}$ & $23.33 \mathrm{H}$ & $23.92 \quad \mathrm{E}$ \\
\hline RECOMMENTED N P K (CONTROL) & $33.33 \mathrm{~B}$ & $32.66 \mathrm{~B}$ & $21.33 \mathrm{M}$ & $21.67 \mathrm{~N}$ \\
\hline
\end{tabular}

*Values followed by the same alphabetical letter(s) in common, within a particular group of means in each character, do not significantly differ, using Revised L.S.D test at 0.05 level of probability

With respect to nitrate accumulation, the application of seaweed extract increased the amount of nitrate in plant leaves. Jainarubens + Bread yeast $5 \%$ and Ulva lactuca + Bread yeast $5 \%$ extracts were found more effective than Jainarubens + Ulva lactuca 40\%. When seaweed biostimulant (Jainarubens + Bread yeast $5 \%$ and Ulva lactuca + Bread yeast $5 \%$ ) extract was incorporated in the medium culture, we noted an important decrease of nitrate accumulation. However, the incorporation of Jainarubens + Ulva lactuca $40 \%$ or Ulva lactuca $40 \%$ extracts in medium culture showed a remarkable increased of nitrate.

This decrease in nitrate accumulation might be due to the consequence of the presence of the high concentration of mineral elements that can inhibit the enzymatic activity. This finding was also reported by Esteban et al., 2004 as the most important enzyme activities within nitrogen metabolism, such as nitrate 
reductase and nitrite reductase, which were affected negatively by the highest $\mathrm{NH}_{4} \mathrm{NO}_{3}$ rate applied to Phaseolus vulgaris plant at different levels.

TABLE 7. Leaf's nitrogen and nitrate content of spnach plants as affected by different concentrations of marine algae and bread yeast as biostimulant during the two winter seasons of 2013/2014 and 2014/2015.

\begin{tabular}{|c|c|c|c|c|}
\hline \multirow[b]{2}{*}{ Treatments } & \multicolumn{2}{|c|}{$\begin{array}{c}\text { Leaf's nitrogen content } \\
(\%)\end{array}$} & \multicolumn{2}{|c|}{ Leaf's nitrate content $(\%)$} \\
\hline & $\begin{array}{l}\text { Winter } \\
\text { 2013/2014 }\end{array}$ & $\begin{array}{c}\text { Winter } \\
\text { 2014/2015 }\end{array}$ & $\begin{array}{l}\text { Winter } \\
2013 / 2014\end{array}$ & $\begin{array}{l}\text { Winter } \\
\text { 2014/2015 }\end{array}$ \\
\hline Bread yeast $5 \%$ & $2.07 \mathrm{AB}$ & $2.09 \mathrm{~A}$ & $0.193 \mathrm{D}-\mathrm{F}$ & $0.21 \mathrm{I}$ \\
\hline Bread yeast $10 \%$ & $1.93 \mathrm{AB}$ & $1.94 \mathrm{AB}$ & $0.19 \mathrm{EF}$ & $0.22 \mathrm{G}-\mathrm{I}$ \\
\hline Bread yeast $20 \%$ & $1.95 \mathrm{AB}$ & $1.96 \mathrm{AB}$ & $0.22 \mathrm{D}$ & $0.23 \mathrm{G}$ \\
\hline Bread yeast $40 \%$ & $2.03 \mathrm{AB}$ & $2.04 \mathrm{AB}$ & $0.36 \mathrm{~A}$ & $0.34 \mathrm{~B}$ \\
\hline Jainarubens $5 \%$ & $2.06 \mathrm{AB}$ & $2.07 \mathrm{~A}$ & $0.135 \mathrm{G}$ & $0.19 \mathrm{JK}$ \\
\hline Jainarubens $10 \%$ & $2.06 \mathrm{AB}$ & $2.06 \quad \mathrm{~A}$ & $0.193 \mathrm{D}-\mathrm{F}$ & $0.216 \mathrm{G}-\mathrm{I}$ \\
\hline Jainarubens $20 \%$ & $2.21 \mathrm{~A}$ & $2.21 \mathrm{~A}$ & $0.193 \mathrm{D}-\mathrm{F}$ & $0.20 \mathrm{~J}$ \\
\hline Jainarubens $40 \%$ & $2.23 \mathrm{~A}$ & $2.27 \mathrm{~A}$ & $0.22 \mathrm{D}$ & $0.243 \mathrm{~F}$ \\
\hline Ulva lactuca $5 \%$ & $2.11 \mathrm{~A}$ & $2.11 \mathrm{~A}$ & $0.153 \mathrm{FG}$ & $0.213 \mathrm{HI}$ \\
\hline Ulva lactuca $10 \%$ & $2.03 \mathrm{AB}$ & $2.04 \quad \mathrm{AB}$ & $0.136 \mathrm{G}$ & $0.123 \mathrm{~L}$ \\
\hline Ulva lactuca $20 \%$ & $2.00 \mathrm{AB}$ & $2.00 \mathrm{AB}$ & $0.358 \mathrm{~A}$ & $0.336 \mathrm{BC}$ \\
\hline Ulva lactuca $40 \%$ & $1.99 \mathrm{AB}$ & $1.99 \mathrm{AB}$ & $0.358 \mathrm{~A}$ & $0.373 \mathrm{~A}$ \\
\hline Jainarubens+ Bread yeast $5 \%$ & $1.99 \mathrm{AB}$ & $2.00 \mathrm{AB}$ & $0.071 \mathrm{H}$ & $0.076 \mathrm{M}$ \\
\hline Jainarubens+ Bread yeast $10 \%$ & $2.10 \mathrm{~A}$ & $2.10 \mathrm{~A}$ & $0.165 \mathrm{FG}$ & $0.18 \mathrm{~K}$ \\
\hline Jainarubens+ Bread yeast $20 \%$ & $2.13 \mathrm{~A}$ & $2.13 \mathrm{~A}$ & $0.18 \mathrm{EF}$ & $0.19 \mathrm{JK}$ \\
\hline Jainarubens+ Bread yeast $40 \%$ & $2.12 \mathrm{~A}$ & $2.12 \mathrm{~A}$ & $0.24 \mathrm{CD}$ & $0.246 \mathrm{~F}$ \\
\hline Ulva lactuca + Bread yeast $5 \%$ & $2.25 \mathrm{~A}$ & $2.25 \mathrm{~A}$ & $0.071 \mathrm{H}$ & $0.076 \mathrm{M}$ \\
\hline Ulva lactuca + Bread yeast $10 \%$ & $2.12 \mathrm{~A}$ & $2.12 \mathrm{~A}$ & $0.18 \mathrm{EF}$ & $0.186 \mathrm{~K}$ \\
\hline Ulva lactuca + Bread yeast $20 \%$ & $2.22 \mathrm{~A}$ & $2.22 \quad \mathrm{~A}$ & $0.22 \mathrm{D}$ & $0.22 \mathrm{G}-\mathrm{I}$ \\
\hline Ulva lactuca + Bread yeast $40 \%$ & $2.16 \mathrm{~A}$ & $2.16 \mathrm{~A}$ & $0.22 \mathrm{D}$ & $0.226 \mathrm{GH}$ \\
\hline Jainarubens+ Ulva lactuca $5 \%$ & $2.22 \mathrm{~A}$ & $2.22 \mathrm{~A}$ & $0.18 \mathrm{EF}$ & $0.18 \mathrm{~K}$ \\
\hline Jainarubens+ Ulva lactuca $10 \%$ & $2.10 \mathrm{~A}$ & $2.10 \mathrm{~A}$ & $0.22 \mathrm{D}$ & $0.22 \mathrm{G}-\mathrm{I}$ \\
\hline Jainarubens+ Ulva lactuca $20 \%$ & $2.23 \mathrm{~A}$ & $2.23 \quad \mathrm{~A}$ & $0.27 \mathrm{C}$ & $0.26 \mathrm{E}$ \\
\hline Jainarubens+ Ulva lactuca $40 \%$ & $2.23 \mathrm{~A}$ & $2.23 \quad \mathrm{~A}$ & $0.311 \mathrm{~B}$ & $0.325 \mathrm{C}$ \\
\hline $\begin{array}{l}\begin{array}{l}\text { RECOMMENTED } \\
\text { (CONTROL) }\end{array} \\
\end{array}$ & $1.77 \mathrm{~B}$ & $1.76 \mathrm{~B}$ & $0.311 \mathrm{~B}$ & $0.31 \mathrm{D}$ \\
\hline
\end{tabular}

*Values followed by the same alphabetical letter(s) in common, within a particular group of means in each column, do not significantly differ, using Revised L.S.D test at 0.05 level of probability.

The data in Table 8 clearly indicated that NPK fertilization (control treatment) had higher leaf's $\mathrm{P}$ content $\%$ than the all different concentration of marine algae during both seasons. For example, in 2013 season, NPK (control) contained 0.55 and $0.56 \%$, respectively also, the higher leaf's $\mathrm{K}$ content \% was reported in Ulva lactuca + Bread yeast $10 \%$ followed by Ulva lactuca + Bread yeast $5 \%$ during both seasons. These results are in agreement with those reported by Stino et al. (2009). This organic fertilization also facilitate the growth of plants by improving the uptake of nutrients and production of some phytohormones. The objective of this research was to provide the potential advantages of biostimulants as organic matter on growth and development of plants.

Egypt. J. Hort. Vol. 43, No.1 (2016) 
THE PROMOTIVE EFFECT OF DIFFERENT CONCENTRATIONS ...

TABLE 8. Leaf's potassium and phosphorus content (\%) of spnach plants as affected by different concentrations of marine algae and bread yeast as biostimulant, during the two winter seasons of 2013/2014 and 2014/2015.

\begin{tabular}{|c|c|c|c|c|}
\hline \multirow{2}{*}{ Treatments } & \multicolumn{2}{|c|}{$\begin{array}{c}\text { Leaf's phosphorus content } \\
(\%)\end{array}$} & \multicolumn{2}{|c|}{$\begin{array}{l}\text { Leaf's potassium } \\
\text { content }(\%)\end{array}$} \\
\hline & $\begin{array}{c}\text { Winter } \\
\text { 2013/2014 }\end{array}$ & $\begin{array}{c}\text { Winter } \\
2014 / 2015\end{array}$ & \begin{tabular}{|c|} 
Winter \\
2013/2014
\end{tabular} & $\begin{array}{c}\text { Winter } \\
2014 / 2015\end{array}$ \\
\hline Bread yeast $5 \%$ & $0.33 \mathrm{~B}-\mathrm{F}$ & $0.34 \mathrm{C}-\mathrm{F}$ & $2.11 \mathrm{~A}-\mathrm{C}$ & $2.12 \mathrm{C}-\mathrm{G}$ \\
\hline Bread yeast $10 \%$ & 0.35 B-E & $0.36 \mathrm{~B}-\mathrm{E}$ & $2.03 \mathrm{BC}$ & $2.10 \mathrm{D}-\mathrm{G}$ \\
\hline Bread yeast $20 \%$ & $0.38 \mathrm{BC}$ & $0.39 \mathrm{BC}$ & $2.08 \mathrm{~A}-\mathrm{C}$ & $2.13 \mathrm{C}-\mathrm{G}$ \\
\hline Bread yeast $\quad 40 \%$ & 0.37 B-D & $0.363 \mathrm{~B}-\mathrm{D}$ & 2.14 A-C & 2.22 A-E \\
\hline Jainarubens $5 \%$ & $0.32 \mathrm{C}-\mathrm{G}$ & $0.33 \mathrm{C}-\mathrm{G}$ & $2.08 \mathrm{~A}-\mathrm{C}$ & $2.12 \mathrm{C}-\mathrm{G}$ \\
\hline Jainarubens $10 \%$ & $0.30 \mathrm{D}-\mathrm{G}$ & $0.31 \mathrm{D}-\mathrm{G}$ & 2016 A-C & $2.16 \mathrm{~B}-\mathrm{F}$ \\
\hline Jainarubens $20 \%$ & $0.286 \mathrm{E}-\mathrm{G}$ & 0.293 E-G & $2.24 \mathrm{~A}-\mathrm{C}$ & $2.19 \mathrm{~B}-\mathrm{F}$ \\
\hline Jainarubens $40 \%$ & $0.26 \mathrm{G}$ & $0.26 \quad \mathrm{G}$ & $2.16 \mathrm{~A}-\mathrm{C}$ & $2.13 \mathrm{C}-\mathrm{G}$ \\
\hline Ulva lactuca $5 \%$ & $0.38 \mathrm{BC}$ & $0.38 \mathrm{BC}$ & $1.98 \mathrm{BC}$ & $1.97 \mathrm{E}-\mathrm{G}$ \\
\hline Ulva lactuca $10 \%$ & $0.41 \mathrm{~B}$ & $0.42 \mathrm{~B}$ & $1.95 \mathrm{C}$ & $1.93 \mathrm{G}$ \\
\hline Ulva lactuca $20 \%$ & $0.38 \mathrm{BC}$ & $0.39 \mathrm{BC}$ & $1.97 \mathrm{BC}$ & $1.95 \mathrm{FG}$ \\
\hline Ulva lactuca $40 \%$ & $0.38 \mathrm{BC}$ & $0.39 \mathrm{BC}$ & $1.98 \mathrm{BC}$ & 1.97 E-G \\
\hline Jainarubens+ Bread yeast $5 \%$ & $0.28 \quad \mathrm{FG}$ & $0.28 \quad \mathrm{FG}$ & $2.14 \quad \mathrm{~A}-\mathrm{C}$ & $2.21 \mathrm{~A}-\mathrm{E}$ \\
\hline Jainarubens+ Bread yeast $10 \%$ & $0.29 \mathrm{D}-\mathrm{G}$ & $0.306 \mathrm{D}-\mathrm{G}$ & $2.18 \mathrm{~A}-\mathrm{C}$ & $2.20 \mathrm{~B}-\mathrm{F}$ \\
\hline Jainarubens+ Bread yeast $20 \%$ & $0.34 \mathrm{~B}-\mathrm{F}$ & $0.35 \mathrm{C}-\mathrm{F}$ & $2.40 \mathrm{~A}$ & $2.41 \mathrm{AB}$ \\
\hline Jainarubens+ Bread yeast $40 \%$ & $0.33 \mathrm{~B}-\mathrm{F}$ & $0.34 \mathrm{C}-\mathrm{F}$ & $2.24 \quad \mathrm{~A}-\mathrm{C}$ & $2.38 \quad \mathrm{~A}-\mathrm{C}$ \\
\hline Ulva lactuca + Bread yeast $5 \%$ & $0.29 \mathrm{D}-\mathrm{G}$ & $0.303 \mathrm{D}-\mathrm{G}$ & $2.31 \mathrm{AB}$ & 2.29 A-D \\
\hline Ulva lactuca + Bread yeast $10 \%$ & 0.28 & $0.293 \mathrm{E}-\mathrm{G}$ & $2.39 \mathrm{~A}$ & $2.46 \mathrm{~A}$ \\
\hline Ulva lactuca + Bread yeast $20 \%$ & 0.283 E-G & $0.29 \mathrm{E}-\mathrm{G}$ & $22.26 \mathrm{~A}-\mathrm{C}$ & 2.32 A-D \\
\hline Ulva lactuca + Bread yeast $40 \%$ & 2.30B-F & 0.29 E-G & $2.30 \mathrm{AB}$ & $2.34 \mathrm{~A}-\mathrm{D}$ \\
\hline Jainarubens+ Ulva lactuca $5 \%$ & $0.34 \mathrm{~B}-\mathrm{F}$ & $0.353 \mathrm{C}-\mathrm{F}$ & $2.19 \quad \mathrm{~A}-\mathrm{C}$ & $2.25 \mathrm{~A}-\mathrm{D}$ \\
\hline Jainarubens+ Ulva lactuca $10 \%$ & 0.36 B-D & $0.366 \mathrm{~B}-\mathrm{D}$ & $2.07 \mathrm{~A}-\mathrm{C}$ & $2.14 \quad \mathrm{C}-\mathrm{G}$ \\
\hline Jainarubens+ Ulva lactuca $20 \%$ & $0.34 \mathrm{~B}-\mathrm{F}$ & $0.35 \mathrm{C}-\mathrm{F}$ & $2.19 \mathrm{~A}-\mathrm{C}$ & $2.15 \mathrm{~B}-\mathrm{G}$ \\
\hline Jainarubens+ Ulva lactuca $40 \%$ & $0.39 \mathrm{BC}$ & $0.39 \mathrm{BC}$ & $2.18 \quad \mathrm{~A}-\mathrm{C}$ & 2.24 A-D \\
\hline RECOMMENTED NP K (CONTROL $)$ & $0.55 \mathrm{~A}$ & $0.56 \mathrm{~A}$ & $2.30 \mathrm{AB}$ & $2.33 \mathrm{~A}-\mathrm{D}$ \\
\hline
\end{tabular}

each column, do not significantly differ, using Revised L.S.D test at 0.05 level of probability

\section{Conclusion}

The present study is an important step towards the utilization of the extracts of the seaweeds to improve yield and growth of spinach plants. The presence of nitrogen, phosphorus, potassium and some trace elements in seaweeds make an excellent choice as biostimulant. All the tested treatments increased plant yield and quality in varying degrees. Ulva lactuca + Bread yeast 5\% was the best treatment to increase the yield of Spinach plants in addition was recorded the lowest amount of nitrate in Spinach leaves. The nitrate accumulation was not dependent on the richness of seaweed extract in mineral element particularly nitrogen.

As perspective, we believe that it would be beneficial to carry out more research including characterization of growth hormones and others metabolites. We can also evaluate the effect of seaweed extract on nitrogen metabolism in root and leaves of spinach plants cultivated in medium culture deficiency or richened of mineral elements. 


\section{References}

A.O.A.C. (1990) "Association of Official Agriculture Chemists" $13^{\text {th }}$ ed. Washington, D.C., U.S.A.

Abbas, S.M. (2013) Influence of biostimulants on the growth and on the biochemical composition of Viciafaba CV. Giza 3 beans. Romanian Biotechn. Lett., 18, 80618068 .

Abd El- Moniem, E.A. and Abd-Allah, A.S. (2008) Effect of green algae cells extract as foliar spray on vegetative growth, yield and berries quality of superior grapevines. Am. Euras. J. Agr. Envir. Sci., 4, 427-433.

Abd El-Motty, E.Z., Shahin, M.F., El-Shiekh, M.H. and Abd-El Migeed, M.M. (2010) Effect of algae extract and yeast application on growth, nutritional status, yield and fruit quality of Keittemangotrees. Agr.bio. J. Nor. Ami., 421-429. 2010, Science HuB, http://www.scihub.org/ABJNA

Abd-El Migeed, A.A., El-Sayed, A.B. and Hassan, H.S. (2004) Growth enhancement of olive transplants by broken cells of fresh green algae as soil application. Minufia. J. Agr. Res., 29, 723-737.

Ahmed, F. and Ragab, M. (2002) A new trial to stimulate growth and nutritional status of Picualolive transplants. The Frist International Conf. on olive cultivation, protection and processing 25-27 Sept. El-Arish, Egypt, 19-35.

Al-Shakankery, M., Hamouda, A. and Ammar, M. (2014) The promotive effect of different concentration of marine algae as biofertilizers on growth and yield of maize plants. J. Chem. Biol Phys. Sci., 4 (4), 3201-3211.

Anisimov, M.M., Skriptova, A.V. and Chaikina, EL Klykov, A.G. (2013) Effect of water extracts of seaweeds on the growth of seedling roots of buckwheat. Int. J. Res. Rev. Appl. Sci., 16 (2), 282-287.

Bhosle, N.B., Untawale, A.G. and Dhargalkar, V.K. (1975) Effects of seaweed extract on growth of Phaseolus vulgaris. Ind. J. Mar. Sci., 4, 208-210.

Esteban, S., Rose, M. R., Juan, M.R. and Luis, R. (2004) Changes in biomass, enzymatic activity and protein concentration in roots and leaves of green bean plants Phaseolus vulgaris under high $\mathrm{NH}_{4} \mathrm{NO}_{3}$ application rates. Scientia Horticulture, 99, 237-248.

Faheed, F.A. and Abd-El Fattah, Z. (2008) Effect of Chlorlla vulgaris as Bio-fertilizer on growth parameters and metabolic aspects of Lettuce Plant, J. Agr. Soc. Sci., 4, 165-169.

Hegab, M.Y., Sharawy, A.M. and El-Saida, S.A. (2005) Effect of algae and monopotassium phosphate on growth and fruiting Balady orange Trees. Proc. Frist Sci Conf. Agr. Sci. Fac. Agric., Assuit Univ., 1, 73-84.

Homme, P.M. and Gonzalez, B.J. (1992) Carbohydrate content, frutane and sucrose enzyme activities in root Stubble and leaves of rye grass as affected by sources/ link modification after cutting. J. Plant Physiol., 140, 282-291.

Egypt. J. Hort. Vol. 43, No.1 (2016) 
Karaman, M.R., Brohi, A.R., Günes, A., Inal, A. and Alpaslan, M. (2000) Effect of regional different $\mathrm{N}$ fertilizer applications on nitrate accumulation in winter vegetables grown on Tokat region. Turkish Journal of Agriculture and Forestry, 24 (1), 1-9.

Mady, M.A. (2009) Effect of foliar application with yeast extract and zink on fruit setting Faba bean (Viciafaba). J. Biol. Chem. Enivon. Sci., 4 (2), 109-127.

Martinez-Anoya, M.A., Pilarch, B. and Beneditode, B.C. (1990) Microflora of the sour doughs wheat flour bread interaction between yeast and lactic acid bacteria in wheat doughs and their effects on bead quality. Cereal Chem., 67 (1), 85-91.

Mordogan, N. (2000) Effect of different nitrogen sources and levels on nitrogen compounds in spinach. Ege Univsities Ziraat Fatultesi Dergisi., 37 (1), 121-127.

Paradiso, P.R., de Pascale, S., Barbieri, G. and de Pascale, S. (2001) Effects of water regime. nitrogen content of spinach. Italus, Hortus., 8 (4), 14-21.

Shaaban, M., El-Saady, A.M. and El-Sayed, A. (2010) Green microalgae water extract and micronutrients foliar application as promoters to nutrient balance and growth of wheat. J. Ameri. Sci., 6 (9), 631-636.

Snedecor, G.W. and Cochron, W.G. (1980) "Statistical Methods", $7^{\text {th }}$ ed., Iowa State University Press, Ames, 507p.

Speijers, G.J.A. (1996) Nitrate, in Toxicological evaluation of certain food additives and contaminants in food, World Health Organization, Food Additives Series 35, Geneva, pp. 325-360.

Speijers, G.J.A. and Van den Brandt, P.A. (2003) Nitrate (and potential endogenous formation of N-nitroso compounds). [Online WHO Food Additives Series 50. Available http://www.inchem.org/documents/jecfa/jecmono/v50je06htm [21 July 2004].

Spinelli, F., Giovanni, F., Massimo, N., Mattia, S. and Gugliemo, C. (2009) Perspective on the use of seaweed extract to moderate the negative effects of alternate bearing in apple trees. J. Hort. Sci. Biotechnol., 17, 131- 137.

Stino, R.G., Mohsen, A.T., Maksoud, M.A., Abd El-Migeed, M.M.M., Gomaa, A.M. and Ibrahim, A.Y. (2009) Bio-organic fertilization and its impact on Apricot young trees in newly reclaimed soil. AmerEurasain J. Agric. Environ. Sci., 6 (1), 62-69.

Walker, R. (1990) Nitrates, nitrites and N-nitroso compounds: a review of the occurrence in food and diet and the toxicological implications. Food Addit. Contam., 7, 717-768.

Wang, Z.H. and Li, S.X. (2003) Effects of $\mathrm{N}$ forms and rates on vegetable growth and nitrate accumulation. Pedosphere, 13 (4), 309-316.

Yadava, U.L. (1986) A rapid and non-destruction method to determine chlorophyll in intact leaves. Hort. Science., 21, 1449-1450.

(Received $11 / 2 / 2016$

accepted $8 / 5 / 2016$ )

Egypt. J. Hort. Vol. 43, No.1 (2016) 


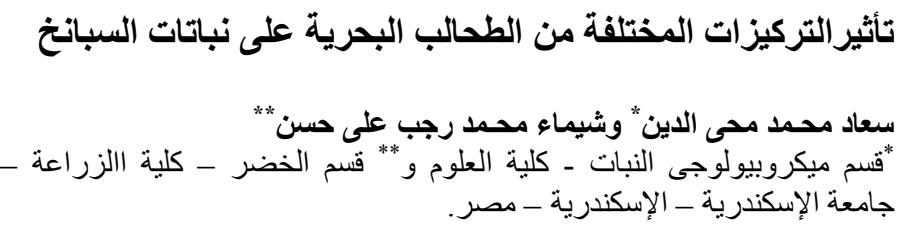

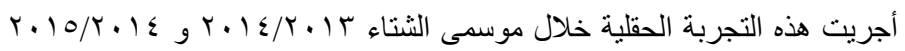

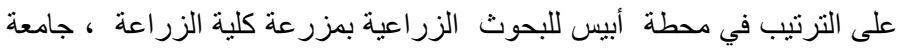

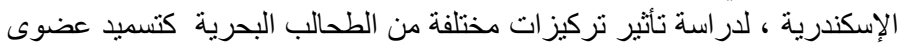

مقارنة مع التسميد المعدني (Bread yeast-Jainarubens-Ulva lactuca)

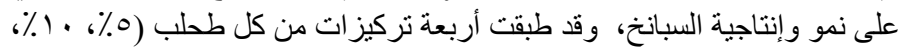

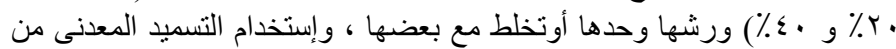

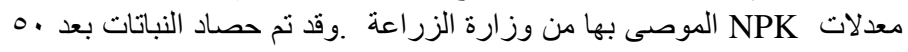

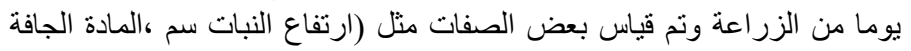

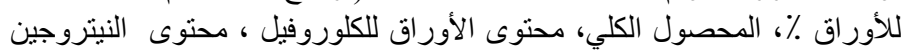

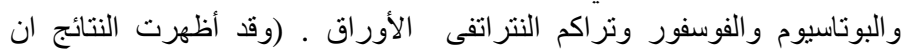

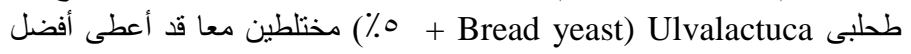

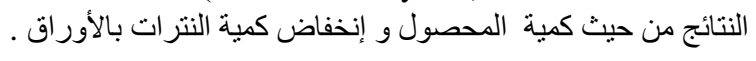

